Article

\title{
Socio-Educational Impact of Augmented Reality (AR) in Sustainable Learning Ecologies: A Semantic Modeling Approach
}

\author{
José Gómez-Galán ${ }^{1,2}$, Esteban Vázquez-Cano ${ }^{3}{ }^{(0)}$, Antonio Luque de la Rosa ${ }^{4}(\mathbb{C}$ \\ and Eloy López-Meneses $5,6, *$ (D) \\ 1 Department of Education, University of Extremadura, 06006 Badajoz, Spain; jgomez@unex.es or \\ jogomez@uagm.edu \\ 2 College of Education, Ana G. Méndez University—Cupey Campus, San Juan, PR 00926, USA \\ 3 Department of Didactics and School Organization, Faculty of Education, The National Distance Education \\ University (UNED), 28040 Madrid, Spain; evazquez@edu.uned.es \\ 4 Department of Education, University of Almeria, 04120 Almería, Spain; aluque@ual.es \\ 5 Department of Education and Social Psychology, Faculty of Social Sciences, University Pablo de Olavide, \\ 41013 Seville, Spain \\ 6 Research Institute in Social Sciences and Education, Vice-Rectory for Research and Postgraduate, \\ University of Atacama, Copiapó 1530000, Chile \\ * Correspondence: elopmen@upo.es
}

Received: 12 October 2020; Accepted: 30 October 2020; Published: 2 November 2020

check for updates

\begin{abstract}
The current educational processes must be supported by sustainable learning ecologies, where the digitalization of training is enhanced. In this area, augmented reality (AR) plays an important role. It is a technology that for certain educational goals can facilitate the understanding of the course contents and increase the motivation and interest of the student. This research aims to measure the socio-educational impact that AR presents in the teaching processes of university students of social education. These are professionals in training dedicated, precisely, to social and educational actions. In order to reach the pursued objective, an exploratory study of qualitative and descriptive nature was approached from a methodological conception based on the action-research. The study was carried out during three academic courses and consisted of an experience of integration of AR in the classroom in order to determine which applications, and advantages or limitations of a socio-educational nature, were perceived by the participants in that process. The documents generated were analyzed mainly using semantic methods. The main results were that AR is positive overall for its use in learning processes and, specifically in its field, optimal for the development of professional skills within the framework of social education. As to benefits, it highlighted the strengthening of learning dynamism, motivation, and interaction among students; as to limitations, these included the fact that it is not an accessible technology, the need for previous training and that it can reduce sociability. It was also stressed that it can be a useful resource in many areas of social education (childhood and adolescence, gerontology, drug addiction, etc.). In general, therefore, it can be concluded that the use of AR in university training, in this area of knowledge, allows content to be more dynamic and real in a sustainable way, thus achieving a highly transferable and motivating path to develop content and competencies.
\end{abstract}

Keywords: augmented reality; sustainable learning; social education; college students; higher education 


\section{Introduction}

The society of this 21st century is characterized by new virtual and digital ways to access and treat information [1-4]. The new learning scenarios require the planification of new instructional spaces, physical and virtual, and implementation of new digital resources in order to promote a more dynamic teaching-learning process [5-12].

The socio-educational and technological changes of the 21st century have contributed to promoting profound transformations in higher education institutions aimed at strengthening new trends that seek to promote a new education in which technology plays an important role. Its purpose is to configure new learning contexts that are more diverse and sustainable where students become key players in achieving this purpose [13,14]. In turn, as Delgado-Vázquez, et al. [15] point out, these play an enormously rich role and education professionals cannot remain on the sidelines. However, digital competence is not an isolated skill and has to be in direct relation to other competences such as "learning to learn" and "social and civic competence". In the development of a new society and a new education with precise new forms of teaching and learning, augmented reality and other emergent technologies could play an important role [16,17].

From the training field, a wide range of technologies are emerging which help to develop digital skills, including augmented reality (AR). This is one of the technologies, within the set of virtual reality (VR) and what it provides in educational settings, which can offer a greater impact on education [17-23], especially in higher education [24,25], and has been developing in recent years thanks to mobile digital devices that facilitate access to the general public [26].

Different authors $[27,28]$ express that AR is the environment in which the integration of the virtual and the real takes place; that is, combining virtual and digital information with a simulated real situation or object through software and a digital device. This technology also allows the display of information by providing multimedia materials or texts linked to objects or places in a simple and immediate way [29] and addressing all the human senses of perception. However, the most common variation of AR is the representation of visual virtual information added to the real environment [30]. AR offers numerous educational possibilities and an immense potential to improve learning and teaching [31-34]. In addition, it provides users with access to rich, varied, and meaningful multimedia content, giving them a relevant context in which to interact immediately [35].

For example, AR helps students to conduct real-world explorations by showing digital objects and situations that are more difficult to observe from a text, picture or blackboard, even in a video [36,37]. In this way, it facilitates new ways of learning and to interpret the meaning of complex situations or objects [38]. According to Dunleavy, Dede and Mitchell [39], the most significant advantage of AR is the ability to create immersive scenarios which integrate contents, real situations, and competences from a more visual approach. It helps to activate cognitive learning processes-the development of cognitive and spatial skills-in students, regardless of their age and academic level, as well as favoring more motivating, collaborative, and interactive learning scenarios [40-42]. On the other hand, several authors [43-46] indicate among their limitations the lack of teacher training and the scarcity of resources and learning objectives focused on AR.

Several recent publications [47-53] have shown that research in AR covers a wide spectrum of objectives and methods. Studies have shown that the use of AR in formal education could enable teachers to combine AR software to reinforce didactic approaches based on flipped classroom and student-centered projects [54], research-based learning [55], and play-based learning [56]. It is used today at all levels of education, especially from K-12 [57-59] to university level [10,34,60-63].

However, studies that focus on measuring the socio-educational impact that AR has on teaching processes are less frequent [64], as are those on the impression that the use of this technology has on users. For this reason, it should be considered necessary to analyze educational experiences with AR and determine which applications, and advantages or limitations of a socio-educational nature, have been perceived in that process by the participants in the experience. This is the main goal that we pursue in this research, applied in the field of social education. 
It should be noted that, among other benefits, the widespread digitalization of training processes, where a technology such as VR occupies a prominent position, is today essential for a sustainable education. Augmented reality can help make learning much more motivating. The contents are perceived more visually and attractively and allow us to improve the student's attitude and disposition towards learning. It can help increase the collaborative skills of users. In addition, the student is encouraged to approach the contents from an interactive component of spatiality; which generates advantages when it comes to appreciating the spatial structure of objects in 3D, as well as interpreting contents of more scientific subjects or that involve the visualization of three-dimensional elements such as natural science, geography or physics. [65]. Therefore, there is a need today to place ourselves in sustainable learning ecologies [66] that guarantee the presence of virtual education. In this way, we can effectively contribute to the achievement of the Millennium Development Goals (MDGs), postulated by the United Nations (UN), which will allow a true sustainable development in all areas.

\section{Materials and Methods}

\subsection{Objects}

The main objective of this research was to determine to what extent AR can influence the social areas of intervention in the case of social educators in training. The innovative immersive experience that forms the basis of this study was developed during three academic years, through three sessions of two hours each in the classes of Practical and Developmental Teaching (Enseñanzas Prácticas y de Desarrollo, EPD) carried out during two months of each course in the subject "Information and Communication Technologies in Social Education", taught in two degrees of Social Education of the Faculty of Social Sciences of the University Pablo de Olavide, in Seville (Spain). In this educational experience it was sought (a) to know the new applications of AR in training scenarios and their pedagogical possibilities in educational contexts; (b) to generate in the students proactive attitudes before the increased technologies, and (c) to develop in the students competences of didactic use of the applications of AR presented in this formative activity.

In the practical sessions of the experience, 4 AR apps were used: (1) Quiver, an application based on augmented reality and virtuality, consists of coloring printed sheets obtained from the web (http://quivervision.com) and then, with any mobile device through its camera, these colored plates come to life, generating augmentative scenarios to improve learning processes; (2) Chromville, an application similar to the Quiver app, with similar dynamics of plates based on immersive technology for the genesis of augmented fantasy environments through the device's camera (https://chromville.com); (3) Zookazam, an application that allows us to add a wide repertoire of animals of diverse species in our real environment, making possible the recreation of fable scenes (http://www.zookazam.com); and (4) Anatomy $4 D$, an AR app in which the student can know the interior of the human body and make a virtual trip to study organs, apparatuses and systems of the human body (https://daqri.com).

\subsection{Research Design and Study Sample}

In order to achieve the objective pursued, an exploratory study of a qualitative and descriptive nature was undertaken. The starting point was a methodological concept based on action research $[67,68]$, in this case virtual collaboration by university students as a way of promoting their own generic and specific skills in the European Higher Education Area [69]. At the end of the experience, the students answered the open questionnaire "Didactic use of AR", where they inserted various texts describing their experience in these VR sessions and describing the advantages and disadvantages they found for the social areas of intervention typical of their profession. The design of the questionnaire was based on the theoretical considerations made by Barroso and Gallego-Pérez [70] and was reviewed by experts in two rounds using the Delphi study.

The qualitative analysis of the information obtained through these texts was based on a process of codification and categorization of the information obtained from them and structured in two stages: 
(a) descriptive stage; and (b) interpretative stage. In turn, the procedure was organized into three phases: Phase 1: Segmentation and identification of units of meaning and grouping into descriptive categories; Phase 2: Construction of a system of emerging thematic nuclei or metacategories; and Phase 3: Identification of qualitative domains (sequential and transversal analysis of metacategories).

The participating sample was composed of 344 students from academic years 2016-2017 (8 men and 58 women); 2017-2018 (5 men and 53 women) and 2018-2019 (4 men and 54 women). In social education degrees this is the usual percentage difference between men and women.

\subsection{Method}

The documentary analysis of the texts obtained was carried out using semantic methods. The proposed approach uses different methods based on semantics and similarity measures to reduce the huge number of extracted textual characteristics and, consequently, reduce spatial and temporal complexities [71-74]. We applied a text network analysis method based on the analysis of students' perception of AR in three dimensions (areas of intervention with the support of AR, benefits of AR, and limitations of AR) [75,76]. The purpose is to identify main topics from text by identifying the clusters of co-occurrent words within them, based on the bag-of-words and skip-gram models [77-79]. For this purpose, we used the software InfraNodus, written in JavaScript (Node.Js), implementing Sigma Js, Cytoscape and Graphology libraries in the front end and a Java-based Neo4J graph database. First, all the words in the text are converted into their lemmas to reduce redundancy, keeping the morphological root of each word.

Liaisons, prepositions and articles are removed from the text, then it is converted into a network graph. Lemmas (words with a complete meaning) are the nodes and their co-occurrences are the edges. This application of graph theory helps gain a better understanding of the textual discourse structure of the relationships between "augmented reality" and its "limitations" and "benefits", identifying the semantic structure of the students' perception. Likewise, to complement the general perception of the students, we analyzed the bigrams associated with each of the three areas (areas of intervention with the support of AR, benefits of AR and limitations of AR) in order to go further into the relationships between concepts and their impact on learning.

\section{Results}

In Figure 1, we observe that the highest intermediation values for the 74,976 words analyzed in the students' written interviews on the social areas of intervention with the support of augmented reality. The graph representation method was applied to these 20 terms to determine the most important relations between social education and AR. It can be observed the importance of three clusters: "childhood" (light orange color), "elderly" (orange color) and "applied technology to learning" (pink color).

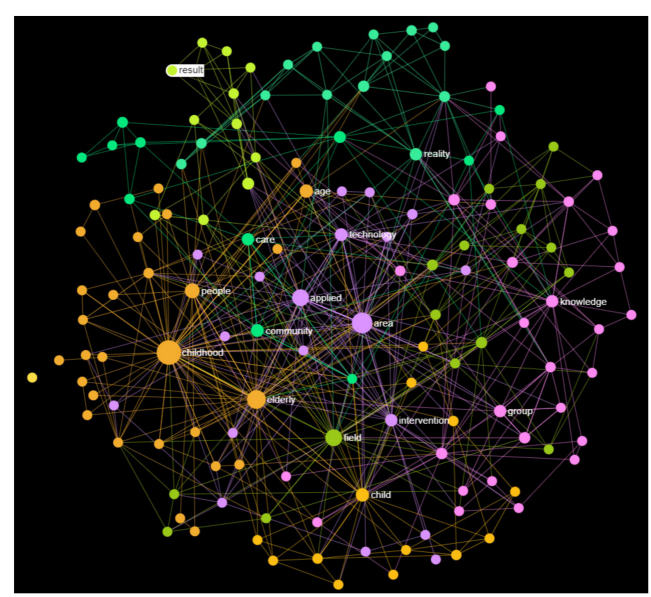

Figure 1. Mapping graph: social intervention with support of augmented reality. 
In Table 1, the mapping of terms and degrees of frequency, conductivity and betweenness of educational benefits of AR are shown.

Table 1. Mapping of degree of frequency of main areas of intervention with the support of AR.

\begin{tabular}{cccccccc}
\hline Node & Degree & Frequency & Betweenness & Topic & Conductivity & Locality & Diversivity \\
\hline childhood & 59 & 108 & 0.433977 & 54 & 73.6 & 1 & 40.2 \\
elderly & 43 & 43 & 0.342264 & 48 & 56.3 & 1 & 56.3 \\
learning & 39 & 5 & 0.239831 & 30 & 21 & 1 & 79.7 \\
adaptability & 25 & 17 & 0.185106 & 24 & 56.7 & 0 & 50.1 \\
additions & 23 & 4 & 0.135080 & 20 & 27 & 0 & 87.7 \\
care & 12 & 11 & 0.858935 & 15 & 49.1 & 0 & 53.6 \\
community & 11 & 11 & 0.670722 & 15 & 64.3 & 0 & 64.3 \\
age & 6 & 1 & 0.300050 & 13 & 0.1 & 72 & 0.5 \\
functional & 6 & 5 & 0.200200 & 14 & 0.3 & 18 & 0.4 \\
\hline
\end{tabular}

Regarding the areas of intervention, we can observe that "childhood" (Dgr. 49/Betw. 0.433977); "elderly" (Dgr. 43/Betw. 0.342264); "learning" (Dgr. 19/Betw. 0.239831); "additions" (Dgr. 49/Betw. 0.433977), "adaptability" (Dgr. 25/Betw. 0.185106); "care" (Dgr. 12/Betw. 0.858935); and "community" (Dgr. 12/Betw. 0.670722).

With regard to the socio-educational benefits of using AR, Figure 2 shows the main results from the analysis. There are three clusters of meanings: "educational motivation and attention" (orange color), "feedback and interactivity" (green color) and "entertainment and enjoyable" (light green color).

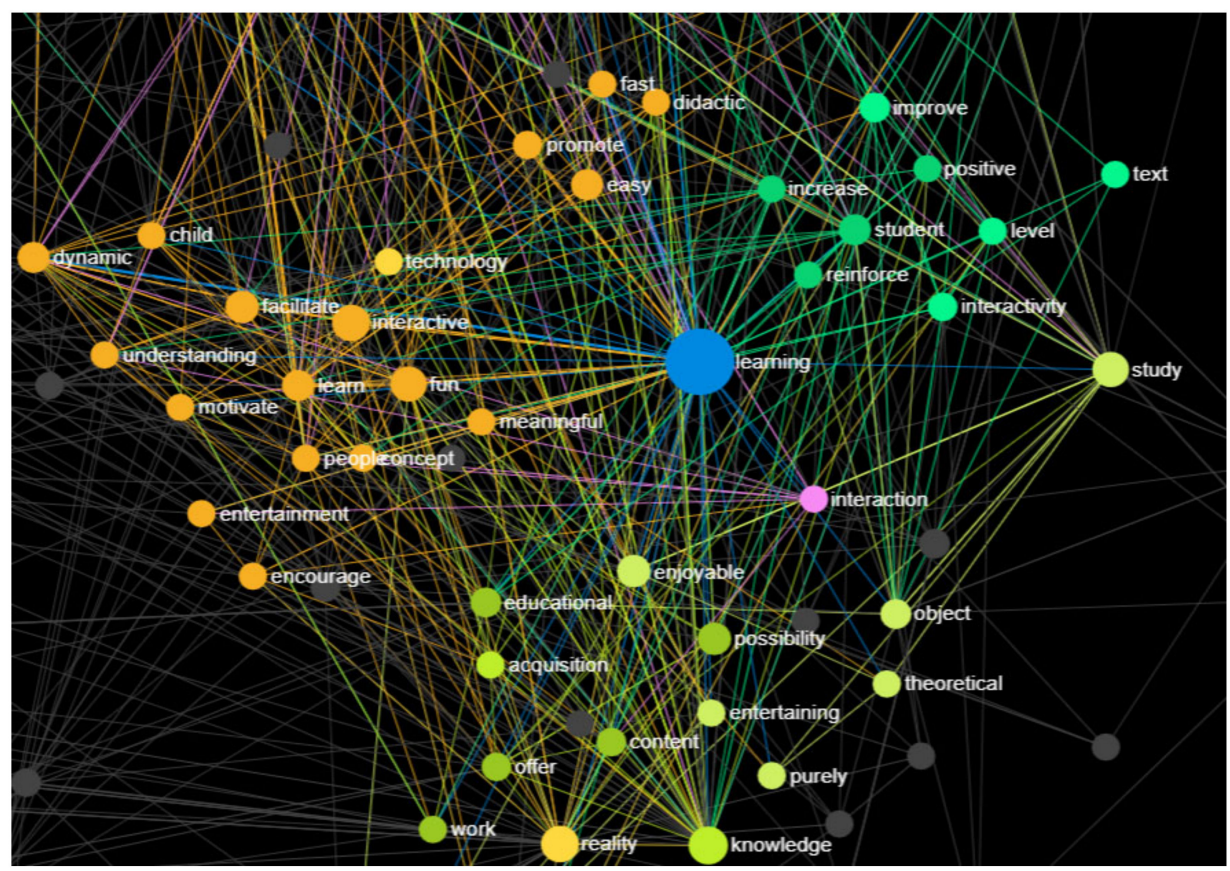

Figure 2. Mapping graph: educational benefits of AR.

In Table 2, the mapping of terms and degrees of frequency, conductivity and betweenness of educational benefits of AR are shown. 
Table 2. Mapping of degree of frequency of educational benefits of AR.

\begin{tabular}{cccccccc}
\hline Node & Degree & Frequency & Betweenness & Topic & Conductivity & Locality & Diversivity \\
\hline fun & 79 & 65 & 0.492835 & 33 & 62.4 & 1 & 75.8 \\
dynamic & 52 & 26 & 0.376977 & 31 & 24.1 & 1 & 29.6 \\
facilitate & 51 & 24 & 0.310478 & 29 & 21.7 & 2 & 46 \\
interactive & 34 & 16 & 0.395849 & 14 & 39.9 & 1 & 59.9 \\
entertainment & 20 & 14 & 0.338341 & 13 & 19.2 & 1 & 27.4 \\
enjoyable & 16 & 16 & 0.258135 & 17 & 36.3 & 0 & 96.9 \\
concentration & 12 & 14 & 0.215849 & 19 & 13.2 & 1 & 39.6 \\
attention & 34 & 12 & 0.376713 & 20 & 22.6 & 2 & 63.9 \\
motivation & 31 & 16 & 0.201821 & 24 & 1.7 & 7 & 3 \\
language & 8 & 13 & 0.108888 & 19 & 11.1 & 1 & 29.6 \\
mathematics & 9 & 12 & 0.106349 & 18 & 7.1 & 1 & 21.2 \\
science & 7 & 11 & 0.100574 & 18 & 0.8 & 9 & 1.9 \\
\hline
\end{tabular}

The educational benefits of using AR are diverse: "fun" (Dgr. 79/Betw. 0.0.492835); "dynamic" (Dgr. 52/Betw. 0.376977); "facilitate" (Dgr. 51/Betw. 0.310478); "interactive" (Dgr. 34/Betw. 0.395849), "enjoyable" (Dgr. 16/Betw. 0.258135); "motivation" (Dgr. 31/Betw. 0.201821) and "applied to the development of three subjects: language, mathematics and science".

The main limitations of using AR from the students' perception are shown in Figure 3. There are three clusters of meanings: "device-internet" (orange color), "access" (green color) and "cost" (light green color).

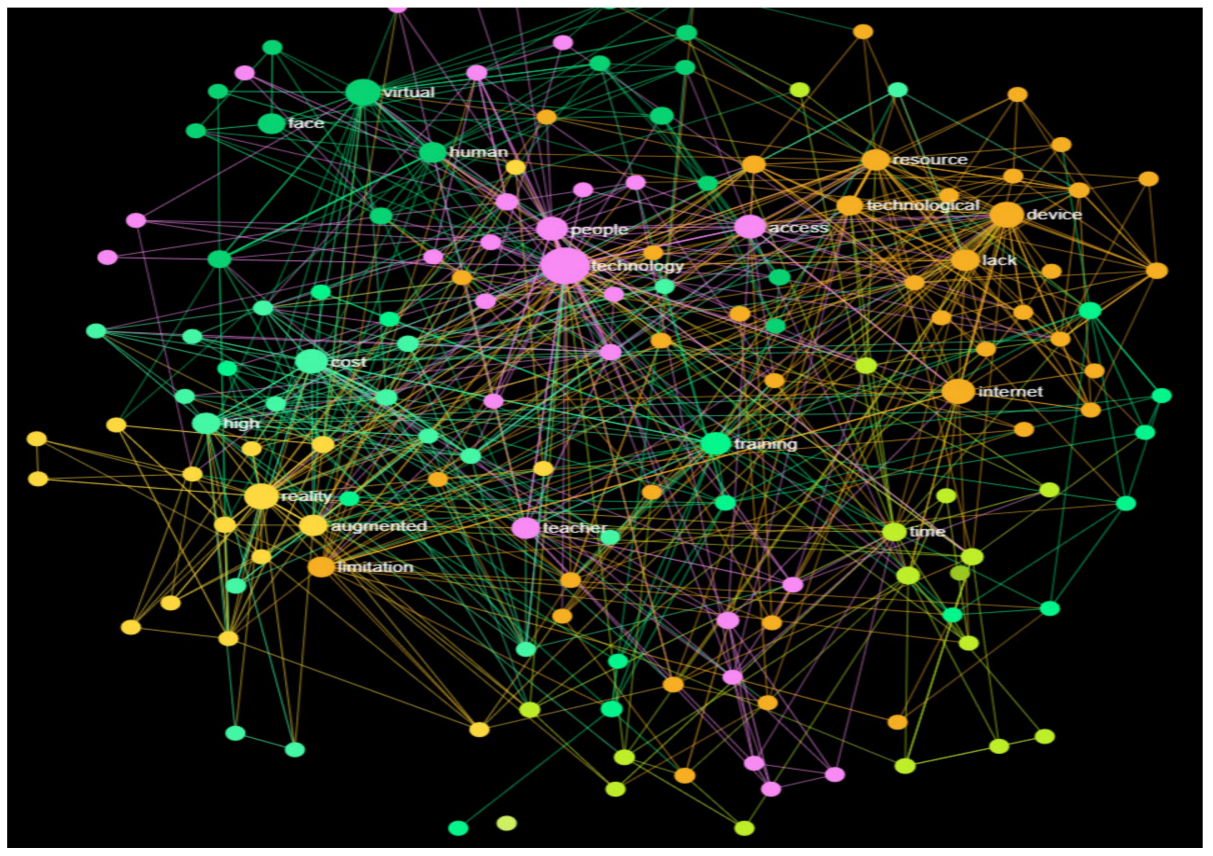

Figure 3. Mapping graph: limitations of AR.

In Table 3, the mapping of terms and degrees of frequency, conductivity and betweenness of limitation of AR are shown. 
Table 3. Mapping of degree of frequency of educational benefits of AR.

\begin{tabular}{cccccccc}
\hline Node & Degree & Frequency & Betweenness & Topic & Conductivity & Locality & Diversivity \\
\hline device & 39 & 29 & 0.226398 & 23 & 32.4 & 1 & 43.6 \\
training & 36 & 29 & 0.203747 & 22 & 28.8 & 1 & 35.8 \\
cost & 29 & 16 & 0.291345 & 14 & 31.5 & 1 & 57.1 \\
economic & 28 & 12 & 0.197746 & 12 & 9.9 & 2 & 14.8 \\
price & 17 & 5 & 0.110589 & 11 & 15.1 & 0 & 21.2 \\
time & 23 & 11 & 0.140140 & 11 & 17.5 & 1 & 36.5 \\
sociability & 22 & 8 & 0.129294 & 9 & 24.4 & 0 & 36.6 \\
\hline
\end{tabular}

The limitations of using AR are in relation to the digital divide, the need for intensive training and the cost of this technology: "device" (Dgr. 39/Betw. 0.226398); "training" (Dgr. 36/Betw. 0.203747); "cost" (Dgr. 29/Betw. 0.291345); "time" (Dgr. 23/Betw. 0.140140), and "sociability" (Dgr. 22/Betw. $0.129294)$.

Likewise, to complement the general perception of the students, we analyzed the bigrams associated with each of the thematic units in order to go further into the relationships between AR and its socio-educational impact. To do this, we used the following notation:

bigram_tf_idf <- bigrams_united $\%>\%$

count(open questions, bigram) $\%>\%$

bind_tf_idf(bigram, open questions, $n) \%>\%$

arrange(desc $\left.\left(t f \_i d f\right)\right)$

We present, in Table 4, the "td_idf" with the highest results of the three most representative bigrams in each of the areas analyzed in order to determine the AR educational functionality.

Table 4. Open questions-bigrams.

\begin{tabular}{ccccc}
\hline Augmented Reality & Bigram & $\mathbf{n}$ & tf & tf_idf \\
\hline \multirow{3}{*}{ Areas of Intervention } & childhood-learning & 54 & 0.11975571 & 0.04339323 \\
& elderly-care & 50 & 0.11775572 & 0.02939291 \\
& adaptability-community & 56 & 0.12775117 & 0.03131370 \\
\hline \multirow{2}{*}{ Benefits } & dynamic-fun & 59 & 0.92612331 & 0.03039671 \\
& motivation-attention & 56 & 0.92975599 & 0.04339375 \\
& interactive-subjects & 53 & 0.12056901 & 0.02935673 \\
\hline \multirow{2}{*}{ Limitations } & digital-divide & 53 & 0.92330731 & 0.02077341 \\
& training-time & 55 & 0.12773363 & 0.02367512 \\
& sociability-reduction & 58 & 0.92765379 & 0.03739712 \\
\hline
\end{tabular}

In Table 4, we can observe that students identify that AR can be an educational resource to teach to children, (tf_idf 0.04339323). They also show that the interactive nature of the AR could be applicable to improve elderly care and the socio-educational impact to foster adaptability in the community (adaptability-community/tf_idf 0.03131370). Regarding the benefits, students perceive that AR is dynamic and fun and that it improves motivation and attention of students (motivation-attention/0.04339375). Likewise, AR increases the interaction in the subjects (interactive-subjects/tf_idf 0.02935673). Finally, the limitations generated by the possibility of using $\mathrm{AR}$ are in relation to the possible digital divide (digital-divide/tf_idf 0.02077341), as well as the need for time for using it (training) (training-time/tf_idf 0.02367512), along with the risk of reduction of sociability (social isolation) (sociability-reduction/tf_idf 0.03739712). 


\section{Discussion}

The results obtained provide us with valuable information on the use of AR in sustainable learning contexts, especially, as has been our case, in the field of social education. In the first instance, it is worth noting that our results are in line with other studies that incorporated these immersive technologies into teaching and learning processes. Students show high levels of satisfaction when participating in these educational experiences [80-84], they are motivated towards these increased processes [85-89] and they improve their academic results $[85,90,91]$.

Similarly, as discussed in another study [82], the use of AR has been useful in building emerging competencies in the use of ICT, teamwork skills and the discovery of new immersive teaching resources useful in social education and social work settings. They were unknown by most of the students, which can help the development of new training processes from an inquiring, constructivist and ubiquitous perspective. These results corroborate other studies that indicate that this emerging technology favors autonomous learning [92] and presents improvements with respect to traditional teaching in aspects of involvement [93], providing content that facilitates the teaching-learning process.

The analysis of the didactic experience of application of the AR with university students allows us to affirm that the use of this technology wakes up motivation among the students. This point has also been corroborated by different studies that show high levels of satisfaction in higher education when students use it in training actions for their professional training [94-98].

According to Fernandez-Robles [99], augmented reality can be presented as a truly useful technology for university education, since it allows for working with active methodologies that offer the possibility of visualizing the object from different perspectives, facilitates the acquisition of knowledge difficult to access, allows the presentation of simulated scenarios and enriches the printed material. Despite these supposed benefits, we believe that proposals and models for the integration of AR should be deepened, taking into account that their development should be properly contextualized. The topics and resources available and the training of teachers should be taken into consideration. Without adequate training, their use can be counterproductive and can lead to a delay in the development of skills and content in teaching programs [100]. In addition, we must bear in mind the possibilities available to educational institutions and students themselves so as not to generate a greater digital divide or discrimination for economic reasons or for access to technology. Likewise, it must be guaranteed that this technology incorporates mechanisms of usability and adaptability to the different special needs that students may have in the classroom [101-103].

University experiences of this type help to expand the theoretical didactic model known as Technology, Pedagogy, Content and Space (TPeCS) [104]. TPeCS maintains that good teaching today requires not only an understanding of how technology relates to pedagogy and content [105], but also an understanding and ability to adapt existing physical spaces, take advantage of alternative spaces or design new ones. This may include the use of digital technologies such as mobile devices, augmented reality, manufacturers' spaces, and, as a focal point for this study, large digital screens [106]. As Cabero and Martínez point out, [107] it is time that we began the transformation from digital literacy to digital competence. Its acquisition must be done through the practices of initial training and promote new training scenarios where the student becomes both an emitter and a receiver of technological messages.

Therefore, it can be considered that the challenge for universities, in this framework, lies in redesigning their training matrices around professional skills rather than around traditional subjects. In this way, the development of didactic proposals involving collaborative work for the promotion of significant learning will be promoted $[108,109]$ along with the progressive increase in the teaching activity of the use of electronic educational resources [110,111]. Ultimately, according to Cabero et al. [28], augmented reality can be an interesting emerging techno-social trend, efficient in educational contexts, which would help the genesis of curricular innovation processes in today's classrooms. 


\section{Conclusions}

In this research we have been able to confirm that the use of AR in the university environment, specifically in social education students, has been positive. The subjects who have participated in the study identify this technology as suitable for their didactic use. They have presented as advantages that it is dynamic and fun, raises motivation and attention, and enhances interaction between people. On the other hand, they have also found some disadvantages, such as the fact that it can increase the digital gap, as it is not accessible to everyone, that it requires a moderate training time and that it reduces sociability and contributes to social isolation.

In the field of social education itself, they consider that $\mathrm{AR}$ is very interesting as an educational resource to teach children, that it can improve the care of the elderly and, also, has a great socio-educational impact to encourage activity in the community. Specifically, they have pointed out that these virtual technologies can be of special interest for the treatment of drug addiction problems and their prevention among adolescents, the disability associated with dementia in the elderly, and the educational facet in childhood and the education of adolescents in formal and non-formal education. The application of this technology in the psychosocial treatment of these problems could improve the acquisition of skills by professionals and also serve to support and improve the conditions and treatment of the aspects outlined in the different social groups.

In general, the perception of higher education students in the areas of social sciences has shown that the use of AR-based activities enables greater reflection and increases the positive attitude and cognitive processes applied to the contents of the degrees in education and social work. On the other hand, as can also be inferred from the analysis of the results, it is interesting to see how AR is applicable not only in the teaching-learning process, but also as a useful resource with great potential in the performance of professional skills.

In addition, AR can help students acquire a series of skills necessary to access other content and to put them into practice in the world of work. It is especially relevant for social science studies in which video simulations of problematic situations related to bullying or gender violence can be generated, and suitable responses can be rehearsed to put into practice in a fictitious way. This allows a better understanding of how to act in real situations, makes the theoretical content more attractive and, therefore, increases student motivation and academic performance. However, even though it offers undoubted benefits, we must also bear in mind its disadvantages. AR technologies require training of teachers, they are not accessible to everyone and they are not suitable for certain people. As it happens with any didactic resource, AR's suitability to be used in order to achieve certain training objectives must be previously evaluated. If it is finally determined that its use would be advisable, the results obtained will probably be excellent and its educational possibilities are very high.

Author Contributions: Conceptualization, J.G.-G., E.V.-C., A.L.d.1.R., E.L.-M.; methodology, J.G.-G., E.V.-C., A.L.d.1.R., E.L.-M.; validation, J.G.-G., E.V.-C., A.L.d.l.R., E.L.-M.; formal analysis, J.G.-G., E.V.-C.; investigation, J.G.-G., E.V.-C., A.L.d.1.R., E.L.-M.; data curation, J.G.-G., E.V.-C.; writing-original draft preparation, J.G.-G., E.V.-C., A.L.d.l.R., E.L.-M.; writing—review and editing, J.G.-G., E.V.-C., E.L.-M.; supervision, J.G.-G., E.V.-C., A.L.d.I.R., E.L.-M.; project administration, J.G.-G., E.V.-C., A.L.d.l.R., E.L.-M. All authors have read and agreed to the published version of the manuscript.

Funding: This research received no external funding.

Acknowledgments: This study originated in the directive established in the Innovation in Education with ICT 2.0 in the European Higher Education Space, developed within the framework of the Innovation and Development in Education projects organized by the Universidad Pablo de Olavide de Sevilla, and financed by that university's Vice-Rectorate for Education and European Convergence, and with the support of members of the EduInnovagogía ${ }^{\circledR}$ (HUM-971) research group. This group is recognized by the Andalusian Plan for Research, Development and Innovation, and the Research Results Transfer Office at the UPO.

Conflicts of Interest: The authors declare no conflict of interest. 


\section{References}

1. Skobelev, P.O.; Borovik, S.Y. On the way from Industry 4.0 to Industry 5.0: From digital manufacturing to digital society. Ind. 4.0 2017, 2, 307-311.

2. Housley, W.; Smith, R.J. Interactionism and digital society. Qual. Res. 2017, 17, 187-201. [CrossRef]

3. Lanier, J.; Weyl, E.G. A blueprint for a better digital society. Harv. Bus. Rev. 2018, 26, 18.

4. Dufva, T.; Dufva, M. Grasping the future of the digital society. Futures 2019, 107, 17-28. [CrossRef]

5. Gómez-Galán, J.; Mateos, S. Versatile Spaces for the Use of the Information Technology in Education. In Advances in Systems Engineering, Signal Processing and Communications; Mastorakis, N., Ed.; WSEAS Press: New York, NY, USA, 2002; pp. 351-361.

6. Thomas, H. Learning spaces, learning environments and the dis 'placement'of learning. Br. J. Educ. Technol. 2010, 41, 502-511. [CrossRef]

7. King, H. Learning spaces and collaborative work: Barriers or supports? High. Educ. Res. Dev. 2016, 35, 158-171. [CrossRef]

8. Trentin, G. Always-on education and hybrid learning spaces. Educ. Technol. 2016, 56, 31-37.

9. De Laat, M.; Dohn, N.B. Is networked learning postdigital education? Postdigital Sci. Educ. 2019, 1, 17-20. [CrossRef]

10. Sáez-López, J.M.; Cózar-Gutiérrez, R.; González-Calero, J.A.; Carrasco, C.J.G. Augmented reality in higher education: An evaluation program in initial teacher training. Educ. Sci. 2020, 10, 26. [CrossRef]

11. Das, K. The role and impact of ICT in improving the quality of education: An overview. Int. J. Innov. Stud. Sociol. Humanit. 2019, 4, 97-103.

12. Rensink, C. Global competence for today and the future. Child. Educ. 2020, 96, 14-21. [CrossRef]

13. Vázquez-Cano, E.; Reyes, M.; Colmenares, L.; López-Meneses, E. Competencia digital del alumnado de la Universidad Católica de Santiago de Guayaquil. Rev. Opción 2017, 83, 229-251.

14. Veytia, M.G.; Gómez-Galán, J.; Cevallos, M.B. Competencias investigativas y mediación tecnológica en doctorandos de Iberoamérica. IJERI Int. J. Educ. Res. Innov. 2019, 12, 1-19.

15. Delgado-Vázquez, A.; Vázquez-Cano, E.; Belando-Montoro, M.R.; López-Meneses, E. Análisis bibliométrico del impacto de la investigación educativa en diversidad funcional y competencia digital: Web of Science y Scopus. Aula Abierta 2019, 48, 147-156. [CrossRef]

16. Rodríguez-García, A.M.; Raso-Sánchez, F.; Ruiz-Palmero, J.R. Competencia digital, educación superior y formación del profesorado: Un estudio de meta-análisis en la Web of Science. Pixel Bit. Rev. Medios Educ. 2019, 54, 65-81. [CrossRef]

17. Gisbert, M.; Lázaro, J.L. Professional development in teacher digital competence and improving school quality from the teachers' perspective: A case study. J. New Approaches Educ. Res. 2015, 4, 115.

18. Gómez-Galán, J. Aplicaciones Didácticas y Educativas de las Tecnologías RIV (Realidad Infovirtual) en Entornos Telemáticos. In Actas del XIII Congreso Internacional de Ingeniería Gráfica: Eliminando Fronteras entre lo Real y lo Virtual; Cuartero, A., Felicísimo, A.M., Ariza, F.J., Eds.; AEIA-UEX: Badajoz, Spain, 2001; pp. $29-43$.

19. Gómez-Galán, J. Education and Virtual Reality. Versatile Spaces for the Use of the Information Technology in Education. In Advances in Systems Engineering, Signal Processing and Communications; Mastorakis, N., Ed.; WSEAS Press: New York, NY, USA, 2002; pp. 345-350.

20. Hood, K. Telling active learning pedagogies apart: From theory to practice. J. New Approaches Educ. Res. 2017, 6, 144-152. [CrossRef]

21. Moreno-Martínez, N.; Leiva, J.J. Experiencias formativas de uso didáctico de la realidad aumentada con alumnado del grado de educación primaria en la universidad de Málaga. EDMETIC Rev. Educ. Mediát. TIC 2017, 6, 81-104. [CrossRef]

22. Huang, K.T.; Ball, C.; Francis, J.; Ratan, R.; Boumis, J.; Fordham, J. Augmented versus virtual reality in education: An exploratory study examining science knowledge retention when using augmented reality/virtual reality mobile applications. Cyberpsychol. Behav. Soc. Netw. 2019, 22, 105-110. [CrossRef]

23. Beck, D. Augmented and virtual reality in education: Immersive learning research. J. Educ. Comput. Res. 2019, 57, 1619-1625. [CrossRef]

24. González-Zamar, M.D.; Abad-Segura, E. Implications of virtual reality in arts education: Research analysis in the context of higher education. Educ. Sci. 2020, 10, 225. [CrossRef] 
25. Radianti, J.; Majchrzak, T.A.; Fromm, J.; Wohlgenannt, I. A systematic review of immersive virtual reality applications for higher education: Design elements, lessons learned, and research agenda. Comput. Educ. 2020, 147, 103778. [CrossRef]

26. Cabero, J.; Barroso, J. Los escenarios tecnológicos en Realidad Aumentada (RA): Posibilidades educativas en estudios universitarios. Aula Abierta 2018, 47, 327-336. [CrossRef]

27. Johnson, L.; Becker, S.A.; Cummins, M.; Estrada, V.; Freeman, A.; Hall, C. NMC Horizon Report: 2016 Higher Education Edition; The New Media Consortium: Austin, TX, USA, 2016.

28. Cabero, J.; Barroso, J.; Llorente, C.; Fernández-Martínez, M.M. Educational uses of augmented reality (AR): Experiences in educational science. Sustainability 2019, 11, 4990. [CrossRef]

29. Billinghurst, M.; Kato, H.; Poupyrev, I. The magicbook-moving seamlessly between reality and virtuality. IEEE Comput. Graph. Appl. 2001, 21, 6-8.

30. Chen, C.M.; Tsai, Y.N. Interactive augmented reality system for enhancing library instruction in elementary schools. Comput. Educ. 2012, 59, 638-652. [CrossRef]

31. Dunleavy, M.; Dede, C.; Mitchell, R. Affordances and limitations of immersive participatory augmented reality simulations for teaching and learning. J. Sci. Educ. Technol. 2009, 18, 7-22. [CrossRef]

32. Herbert, B.; Ens, B.; Weerasinghe, A.; Billinghurst, M.; Wigley, G. Design considerations for combining augmented reality with intelligent tutors. Comput. Graph. 2018, 77, 166-182. [CrossRef]

33. Kiryakova, G.; Angelova, N.; Yordanova, L. The potential of augmented reality to transform education into smart education. TEM J. 2018, 7, 556.

34. Radosavljevic, S.; Radosavljevic, V.; Grgurovic, B. The potential of implementing augmented reality into vocational higher education through mobile learning. Interact. Learn. Environ. 2020, 28, 404-418. [CrossRef]

35. Hung, P.H.; Hwang, G.J.; Lin, Y.F.; Wu, T.H.; Su, I.H. Seamless connection between learning and assessmentapplying progressive learning tasks in mobile ecology inquiry. Educ. Technol. Soc. 2013, 16, 194-205.

36. Javornik, A.; Kostopoulou, E.; Rogers, Y.; gen Schieck, A.F.; Koutsolampros, P.; Moutinho, A.; Julier, S. An experimental study on the role of augmented reality content type in an outdoor site exploration. Behav. Inf. Technol. 2019, 38, 9-27. [CrossRef]

37. Wu, H.K.; Lee, S.W.; Chang, H.Y.; Liang, J.C. Current status, opportunities and challenges of augmented reality in education. Comput. Educ. 2013, 62, 41-49. [CrossRef]

38. Sotiriou, S.; Bogner, F.X. Visualizing the invisible: Augmented reality as an innovative science education scheme. Adv. Sci. Lett. 2008, 1, 114-122. [CrossRef]

39. Dunleavy, M.; Dede, C. Augmented Reality Teaching and Learning. In Handbook of Research on Educational Communications and Technology; Springer: New York, NY, USA, 2014; pp. 735-745.

40. Ibáñez, M.B.; Delgado-Kloos, C. Augmented reality for STEM learning: A systematic review. Comput. Educ. 2018, 123, 109-123. [CrossRef]

41. Lai, A.F.; Chen, C.H.; Lee, G.Y. An augmented reality-based learning approach to enhancing students' science reading performances from the perspective of the cognitive load theory. Br. J. Educ. Technol. 2019, 50, 232-247. [CrossRef]

42. Thees, M.; Kapp, S.; Strzys, M.P.; Beil, F.; Lukowicz, P.; Kuhn, J. Effects of augmented reality on learning and cognitive load in university physics laboratory courses. Comput. Hum. Behav. 2020, 108, 106316. [CrossRef]

43. Saltan, F.; Arslan, O. The use of augmented reality in formal education: A scoping review. Eurasia J. Math. Sci. Technol. Educ. 2016, 13, 503-520. [CrossRef]

44. Quintero, J.; Baldiris Navarro, S.M.; Rubira, R.; Cerón, J.; Velez, G. Augmented reality in educational inclusion. A Systematic review on the last decade. Front. Psychol. 2019, 10, 1835. [CrossRef]

45. Tzima, S.; Styliaras, G.; Bassounas, A. Augmented reality applications in education: Teachers point of view. Educ. Sci. 2019, 9, 99. [CrossRef]

46. Abad-Segura, E.; González-Zamar, M.D.; Luque, A.; Morales, M.B. Sustainability of educational technologies: An approach to augmented reality research. Sustainability 2020, 12, 4091. [CrossRef]

47. Akçayır, M.; Akçayır, G. Advantages and challenges associated with augmented reality for education: A systematic review of the literature. Educ. Res. Rev. 2017, 20,1-11. [CrossRef]

48. Sirakaya, M.; Alsancak, D. Trends in educational augmented reality studies: A systematic review. Malays. Online J. Educ. Technol. 2018, 6, 60-74. [CrossRef] 
49. Arici, F.; Yildirim, P.; Caliklar, S..; Yilmaz, R.M. Research trends in the use of augmented reality in science education: Content and bibliometric mapping analysis. Comput. Educ. 2019, 142, 103647. [CrossRef]

50. Garzón, J.; Pavón, J.; Baldiris, S. Systematic review and meta-analysis of augmented reality in educational settings. Virtual Real. 2019, 23, 447-459. [CrossRef]

51. Sirakaya, M.; Alsancak, D. Augmented reality in STEM education: A systematic review. Interact. Learn. Environ. 2020, 27, 1-14. [CrossRef]

52. Sahin, D.; Yilmaz, R.M. The effect of Augmented Reality Technology on middle school students' achievements and attitudes towards science education. Comput. Educ. 2020, 144, 103710. [CrossRef]

53. Baragash, R.S.; Al-Samarraie, H.; Alzahrani, A.I.; Alfarraj, O. Augmented reality in special education: A meta-analysis of single-subject design studies. Eur. J. Spec. Needs Educ. 2020, 35, 382-397. [CrossRef]

54. Crandall, P.G.; Engler, R.K.; Beck, D.E.; Killian, S.A.; O’Bryan, C.A.; Jarvis, N.; Clausen, E. Development of an augmented reality game to teach abstract concepts in food chemistry. J. Food Sci. Educ. 2015, 14, 18-23. [CrossRef]

55. Wang, H.Y.; Duh, H.B.; Li, N.; Lin, T.J.; Tsai, C.C. An investigation of university students' collaborative inquiry learning behaviors in an augmented reality simulation and a traditional simulation. J. Sci. Educ. Technol. 2014, 23, 682-691. [CrossRef]

56. Hwang, G.J.; Wu, P.H.; Chen, C.C.; Tu, N.T. Effects of an augmented reality-based educational game on students' learning achievements and attitudes in real-world observations. Interact. Learn. Environ. 2015, 24, 1895-1906. [CrossRef]

57. Maas, M.J.; Hughes, J.M. Virtual, augmented and mixed reality in K-12 education: A review of the literature. Technol. Pedagog. Educ. 2020, 29, 231-249. [CrossRef]

58. Ping, L.; Liu, K. Using the technology acceptance model to analyze K-12 students' behavioral intention to use augmented reality in learning. Tex. Educ. Rev. 2020, 8, 37-51.

59. Fransson, G.; Holmberg, J.; Westelius, C. The challenges of using head mounted virtual reality in K-12 schools from a teacher perspective. Educ. Inf. Technol. 2020, 25, 3383-3404. [CrossRef]

60. Scaravetti, D.; Doroszewski, D. Augmented Reality experiment in higher education, for complex system appropriation in mechanical design. Procedia CIRP 2019, 84, 197-202. [CrossRef]

61. Barroso, J.; Gutiérrez-Castillo, J.; Llorente-Cejudo, M.; Ortiz, R.V. Difficulties in the incorporation of augmented reality in university education: Visions from the experts. NAER J. New Approaches Educ. Res. 2019, 8, 126-141. [CrossRef]

62. Halili, S.H. Technological advancements in education 4.0. Online J. Distance Educ. E Learn. 2019, 7, 63-69.

63. Gudoniene, D.; Rutkauskiene, D. Virtual and augmented reality in education. Balt. J. Mod. Comput. 2019, 7, 293-300. [CrossRef]

64. Garzón, J.; Baldiris, S.; Gutiérrez, J.; Pavón, J. How do pedagogical approaches affect the impact of augmented reality on education? A meta-analysis and research synthesis. Educ. Res. Rev. 2020, 2, 100334. [CrossRef]

65. Gómez-Galán, J.; Vergara, D.; Ordóñez-Olmedo, E.; Veytia, M.G. Time of use and patterns of Internet consumption in university students: A comparative study between Spanish-speaking countries. Sustainability 2020, 12, 5087. [CrossRef]

66. Papashane, M.; Hlalele, D. Academic literacy: A critical cognitive catalyst towards the creation of sustainable learning ecologies in higher education. Mediterr. J. Soc. Sci. 2014, 5, 661. [CrossRef]

67. Serpa, S.; Ferreira, C.M.; Santos, A.I.; Teixeira, R. Participatory action research in higher education training. Int. J. Soc. Sci. Stud. 2018, 6, 1-7. [CrossRef]

68. Ronen, I.K. Action research as a methodology for professional development in leading an educational process. Stud. Educ. Eval. 2020, 64, 100826. [CrossRef]

69. Pool-Cibrian, W.J.; Martínez-Guerrero, J.I. Autoeficacia y uso de estrategias para el aprendizaje autorregulado en estudiantes universitarios. Rev. Electrón. Investig. Educ. 2013, 15, 21-37.

70. Barroso, J.; Gallego-Pérez, O.M. Producción de recursos de aprendizaje apoyados en Realidad Aumentada por parte de estudiantes de magisterio. EDMETIC Rev. Educ. Mediát. TIC 2017, 6, 23-38. [CrossRef]

71. Kou, F.; Du, J.; Lin, Z.; Liang, M.; Li, H.; Shi, L.; Yang, C. A semantic modeling method for social network short text based on spatial and temporal characteristics. J. Comput. Sci. 2018, 28, 281-293. [CrossRef]

72. Bahgat, E.M.; Rady, S.; Gad, W.; Moawad, I.F. Efficient email classification approach based on semantic methods. Ain Shams Eng. J. 2018, 9, 3259-3269. [CrossRef] 
73. Kazakov, I.A.; Kustova, I.A.; Mantsivoda, A.V. Document modeling: Methodology and applications. Bull. Irkutsk State Univ. 2020, 32, 79-93. [CrossRef]

74. Kumar, A.A. Semantic memory: A review of methods, models, and current challenges. Psychon. Bull. Rev. 2020, 1-41. [CrossRef] [PubMed]

75. Budan, I.A.; Graeme, H. Evaluating WordNet-based measures of semantic distance. Comput. Linguist. 2006, 32, 13-47.

76. Bullinaria, J.A.; Levy, J.P. Extracting semantic representations from word cooccurrence statistics: Stop-lists, stemming and SVD. Behav. Res. Methods 2012, 44, 890-907. [CrossRef] [PubMed]

77. Jones, M.; Mewhort, D. Representing word meaning and order information in a composite holographic lexicon. Psychol. Rev. 2007, 114, 1-37. [CrossRef] [PubMed]

78. Bruni, E.; Tran, N.K.; Baroni, M. Multimodal distributional semantics. J. Artif. Intell. Res. 2014, 49, 1-47. [CrossRef]

79. Feng, Y.; Bagheri, E.; Ensan, F.; Jovanovic, J. The state of the art in semantic relatedness: A framework for comparison. Knowl. Eng. Rev. 2017, 32,1-30. [CrossRef]

80. Furió, M.C.; Seguí, J.; Vivó, R. Mobile learning vs. Traditional classroom lessons: A comparative study. J. Comput. Assist. Learn. 2015, 31, 189-201. [CrossRef]

81. Bicen, H.; Bal, E. Determination of student opinions in augmented reality. World J. Educ. Technol. Curr. Issues 2016, 8, 205-209. [CrossRef]

82. Cabero, J.; Vázquez-Cano, J.; López-Meneses, E. Uso de la realidad aumentada como recurso didáctico en la enseñanza universitaria. Form. Univ. 2018, 11, 25-34. [CrossRef]

83. Gómez-Galán, J.; López-Meneses, E.; Bernal-Bravo, C.; Vázquez-Cano, E. Virtual and Augmented Reality. In Innovation and ICTs in Education. The Diversity of the 21st Century Classroom; Gómez-Galán, J., Ed.; River Publishers: Aalborg, Denmark, 2020; pp. 191-209.

84. Chang, K.E.; Zhang, J.; Huang, Y.S.; Liu, T.C.; Sung, Y.T. Applying augmented reality in physical education on motor skills learning. Interact. Learn. Environ. 2020, 28, 685-697. [CrossRef]

85. Lu, S.J.; Liu, Y.C. Integrating augmented reality technology to enhance children's learning in marine education. Environ. Educ. Res. 2015, 21, 525-541. [CrossRef]

86. Fombona, J.; Vázquez-Cano, E. Posibilidades de utilización de la Geolocalización y Realidad Aumentada en el ámbito educativo. Educ. XX1 2017, 20, 319-342.

87. Khan, T.; Johnston, K.; Ophoff, J. The impact of an augmented reality application on learning motivation of students. Adv. Hum. Comput. Interact. 2019. [CrossRef]

88. Cabero, J.; Roig-Vila, R. The motivation of technological scenarios in augmented reality (AR): Results of different experiments. Appl. Sci. 2019, 9, 2907. [CrossRef]

89. Chen, M.P.; Wang, L.C.; Zou, D.; Lin, S.Y.; Xie, H.; Tsai, C.C. Effects of captions and English proficiency on learning effectiveness, motivation and attitude in augmented-reality-enhanced theme-based contextualized EFL learning. Comput. Assist. Lang. Learn. 2020, 10, 1-31. [CrossRef]

90. Kamarainen, A.A.; Shari, M.; Tina, G.; Allison, B.; Diana, M.; Shane, T.; Dede, C. EcoMOBILE: Integrating augmented reality and probeware with environmental education field trips. Comput. Educ. 2013, 68, 545-556. [CrossRef]

91. López-Belmonte, J.; Pozo-Sánchez, S.; Fuentes-Cabrera, A.; Romero-Rodríguez, J.M. Eficacia del aprendizaje mediante flipped learning con realidad aumentada en la educación sanitaria escolar. J. Sport Health Res. 2020, $21,11$.

92. Martín-Gutiérrez, J.; Fabiani, P.; Benesova, W.; Meneses, M.D.; Mora, C.E. Augmented reality to promote collaborative and autonomous learning in higher education. Comput. Hum. Behav. 2015, 51, 752-761. [CrossRef]

93. Di Serio, A.; Ibáñez, M.B.; Delgado, C. Impact of an augmented reality system on students' motivation for a visual art course. Comput. Educ. 2013, 68, 586-596. [CrossRef]

94. Cózar, R.; Moya, M.; Hernández, J.; Hernández, J. Tecnologías emergentes para la enseñanza de las Ciencias Sociales. Una experiencia con el uso de Realidad Aumentada en la formación inicial de maestros. Digit. Educ. Rev. 2015, 27, 138-153.

95. Vergara, D.; Rubio, M.P.; Lorenzo, M. On the design of virtual reality learning environments in engineering. Multimodal Technol. Interact. 2017, 1, 11. [CrossRef] 
96. Videnov, K.; Stoykova, V.; Kazlacheva, Z. Application of Augmented Reality in Higher Education. ARTTE Appl. Res. Tech. Technol. Educ. 2018, 6, 1-9. [CrossRef]

97. Extremera, J.; Vergara, D.; Dávila, L.P.; Rubio, M.P. Virtual and augmented reality environments to learn the fundamentals of crystallography. Crystals 2020, 10, 456. [CrossRef]

98. Salar, R.; Arici, F.; Caliklar, S.; Yilmaz, R.M. A Model for augmented reality immersion experiences of university students studying in science education. J. Sci. Educ. Technol. 2020, 29, 257-271. [CrossRef]

99. Fernández-Robles, B. La utilización de objetos de aprendizaje de realidad aumentada en la enseñanza universitaria de educación primaria. IJERI Int. J. Educ. Res. Innov. 2018, 9, 90-104.

100. Gómez-Galán, J. Realidad Virtual en la Arqueología y el Arte: Orientaciones Didácticas y Formativas. In Arte y Sociedad: Bellas Artes y Sociedad Digital; Martínez-Coll, J.C., Ed.; Universidad de Málaga: Málaga, Spain, 2014; pp. 5-17.

101. Cakir, R.; Korkmaz, O. The effectiveness of augmented reality environments on individuals with special education needs. Educ. Inf. Technol. 2019, 24, 1631-1659. [CrossRef]

102. Köse, H.; Güner-Yildiz, N. Augmented reality (AR) as a learning material in special needs education. Educ. Inf. Technol. 2020, 34, 1-16. [CrossRef]

103. Baragash, R.S.; Al-Samarraie, H.; Moody, L.; Zaqout, F. Augmented reality and functional skills acquisition among individuals with special needs: A meta-analysis of group design studies. J. Spec. Educ. Technol. 2020. [CrossRef]

104. Kali, Y.; Sagy, O.; Benichou, M.; Atias, O. Levin-Peled Teaching expertise reconsidered: The Technology, Pedagogy, Content and Spaces (TPeCS) knowledge framework. Br. J. Educ. Technol. 2019, 50, 2162-2177. [CrossRef]

105. Mishra, P.; Koehler, M.J. Technological pedagogical content knowledge: A framework for teacher knowledge. Teach. Coll. Rec. 2006, 108, 1017. [CrossRef]

106. Tissenbaum, M.; Slotta, J.D. Developing a smart classroom infrastructure to support real-time student collaboration and inquiry: A 4-year design study. Instr. Sci. 2019, 47, 423-462. [CrossRef]

107. Cabero, J.; Martínez, A. Las tecnologías de la información y comunicación y la formación inicial de los docentes. Modelos y competencias digitales. Profr. Rev. Curríc. Form. Profr. 2019, 23, 247-268.

108. Gómez-Galán, J.; Vázquez-Cano, E.; López-Meneses, E. Experiencias innovadoras de estudiantes universitarios con software social sobre las ventajas y debilidades de las tecnologías de la información y la comunicación en ámbitos socioeducativos. Hekademos. Rev. Educ. Digit. 2018, 25, 7-15.

109. Concepción, J.D.; Veytia, M.G.; Gómez-Galán, J.; López-Meneses, E. Integrating the digital paradigm in higher education: ICT training and skills of university students in a european context. Int. J. Educ. Excell. 2019, 5, 47-64. [CrossRef]

110. Vázquez-Cano, E.; López Meneses, E.; Sánchez-Serrano, J.L. Analysis of social worker and educator's areas of intervention through multimedia concept maps and online discussion forums higher Education. Electron. J. E Learn. 2015, 13, 333-346.

111. Vázquez-Cano, E.; Marín-Díaz, V.; Oyarvide, W.R.V.; Meneses, E.L. Use of augmented reality to improve specific and transversal competencies in students. Int. J. Learn. Teach. Educ. Res. 2020, 19, 393-408. [CrossRef]

Publisher's Note: MDPI stays neutral with regard to jurisdictional claims in published maps and institutional affiliations.

(C) 2020 by the authors. Licensee MDPI, Basel, Switzerland. This article is an open access article distributed under the terms and conditions of the Creative Commons Attribution (CC BY) license (http://creativecommons.org/licenses/by/4.0/). 